\title{
Idiopathic CD4+ T-Lymphocytopenia in a Non-Hodgkin's Lymphoma Patient
}

\author{
Ichiro Hanamura, Atsushi Wakita, Shinsuke Harada, Kazuya Tsubor, Hirokazu Komatsu, \\ Shogo Banno, Osamu IwaKi*, Genji TaKeuchi*, Masakazu Nitta and Ryuzo UedA
}

\begin{abstract}
We report a case of idiopathic CD4+ T-lymphocytopenia with malignant lymphoma (diffuse large, $B$-cell type) for which there was no evidence of human immunodeficiency virus type 1 or type 2 infection and no other known causes of immunodeficiency. She had never suffered from any opportunistic infection until the diagnosis of malignant lymphoma was made, and the CD4+ Tlymphocytopenia persisted after complete remission of the lymphoma. As the clinical features and immune status of the patient differed from those associated with the acquired immunodeficiency syndrome (AIDS)-related syndrome, we conclude that immunodeficiency in this case did not contribute to the opportunistic infection but may have been associated with the genesis of malignant lymphoma.
\end{abstract}

(Internal Medicine 36: 643-646, 1997)

Key words: human immunodeficiency virus (HIV), malignant lymphoma, chemotherapy

\section{Introduction}

Idiopathic CD4+ T-lymphocytopenia (ICDL) is a rare condition which is manifested by peripheral CD4+ helper/inducer $\mathrm{T}$-cell depression without any evidence of human immunodeficiency virus (HIV) infection (1). However, since CD4+ Tlymphocytopenia is closely related to HIV infection, it has been suggested that some patients with this syndrome may be completely asymptomatic and therefore could easily escape diagnosis when they have no risk factors for HIV infection (2). Previous reports of ICDL have described unexpected severe infections, such as tuberculosis (3), cryptococcus (4), candida albicans (5) or some kind of virus (6). Here we describe a patient with non-Hodgkin's lymphoma, in whom CD4+cells remained persistently depressed and who suffered from severe herpes zoster infection during seven months of chemotherapy.

\section{Case Report}

A 47-year-old Japanese female was admitted to a neighbouring hospital in October 1995, because of a tumor in the right lower quadrant of the abdomen. She was diagnosed as having a right adnexal tumor and underwent trans-vaginal hysterectomy with right salpingo-oophorectomy. At the operation, a right enlarged ovarian tumor $8 \times 9 \mathrm{~cm}$ with a rough surface without adhesion was found. No other abnormal tumor was detected on thorough exploration. Pathological examination of paraffin-embedded sections showed infiltrating medium to large sized lymphocytes and immunohistological analysis of the tumor showed positive staining for L-26 (universal B-cell marker) whereas UCHL-1 (T-cell marker) was negative. A diagnosis of non-Hodgkin's lymphoma, diffuse large cell type, was established (Fig. 1). The test for Epstein-Barr (EB) virus was negative by polymerase chain reaction for EB viral DNA sequences. She was transferred to our hospital for chemotherapy in November 1995. She had no risk factors for HIV infection, no history of sexually transmitted diseases and had never undergone therapy associated with T-cell depletion. She had a five-year history of diabetes mellitus, which was well controlled by diet and exercise therapy. There was no family history of immunodeficiency or serious infections and her husband and two children are in good health.

On admission, physical examination showed a pulse of 80/ min, blood pressure of $110 / 80 \mathrm{mmHg}$ and body temperature of $36.7^{\circ} \mathrm{C}$. Breathing and heart sounds were normal and hepatosplenomegaly was not detected. There was no lymph node swelling. Laboratory data were as follows (Table 1); white blood cells (WBC) $6,900 / \mu 1$ with $14 \%$ lymphocytes and $43 / \mu 1$

From the Second Department of Internal Medıcıne, Nagoya City Unıversity Medıcal School, Nagoya and *Dıvısıon of Hematology and Rheumatology, Shızuoka Saiseıkaı General Hospital, Shızuoka

Received for publicatıon July 29, 1996; Accepted for publıcatıon June 5, 1997

Reprint requests should be addressed to Dr. Ichıro Hanamura, whose present address is Division of Hematology and Rheumatology, Shızuoka Saiseıkaı General Hospital, 1-1, 1-chome Oshıka, Shızuoka 422 


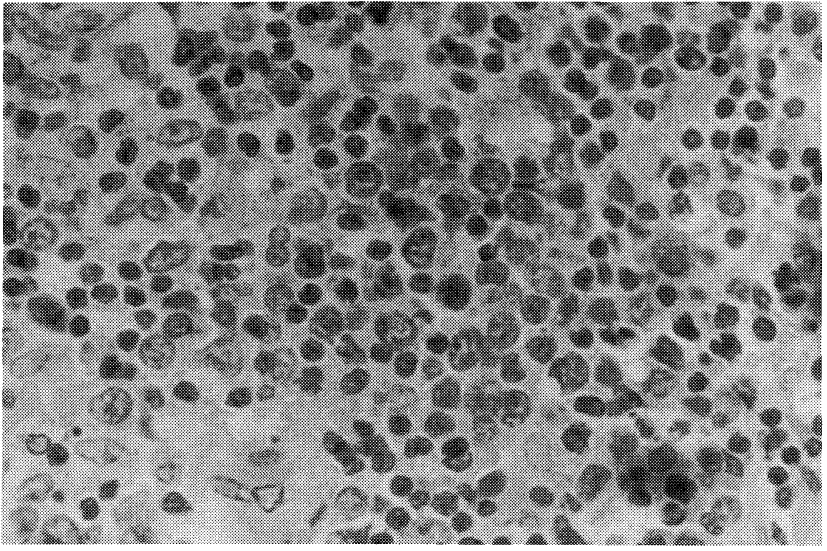

Figure 1. Pathological findings of a resected specimen (HE stain, $\times \mathbf{4 0 0})$. Note the diffuse infiltration of tumor lymphocytes.

CD4+ T-lymphocytes tested with two monoclonal antibodies OKT4 and Leu3a by flow cytometry. The absolute numbers of other subgroups of lymphocytes, CD3+, CD19+ and CD8+, and natural killer cells were in the normal ranges. The CD8+ Tcell percentage was relatively increased and the $\mathrm{CD} 4+/ 8+$ ratio was 0.08 . Bone marrow examination showed normocellularity and no tumor cells. Tests for HIV-1 and HIV-2 were negative by enzyme-linked immunosorbent assay (ELISA) and Western blot analysis. A serum test for human T cell leukemia virus-1 (HTLV1) was negative, but the standard serologic tests for antibodies to Epstein-Barr virus and cytomegalovirus were positive. Skin test for tuberculosis showed anergy. An abdominal US scan showed a low density tumor $3 \times 3.5 \mathrm{~cm}$ in diameter in the left lower abdomen, which could not be precisely located by a computed tomographic scan of the whole body. Gallium radioisotope scanning revealed a hot uptake region in the right subclavicular area, the left hilar region and the left ovary. Her clinical stage was III $_{\mathrm{AE}}$ on the basis of the Ann Arbor classification.

She received combination chemotherapy with the VABCOPM protocol, which consists of vincristine $\left(1 \mathrm{mg} / \mathrm{m}^{2}\right)$, adriamycin $\left(70 \mathrm{mg} / \mathrm{m}^{2}\right)$, mitoxantrone $\left(10 \mathrm{mg} / \mathrm{m}^{2}\right)$, etoposide $\left(67 \mathrm{mg} / \mathrm{m}^{2}\right.$ $\times 3)$, cyclophosphamide $\left(350 \mathrm{mg} / \mathrm{m}^{2}\right)$, bleomycin $\left(6 \mathrm{mg} / \mathrm{m}^{2}\right)$ and methotrexate $\left(200 \mathrm{mg} / \mathrm{m}^{2}\right)$ by intravenous administration and prednisolone $\left(40 \mathrm{mg} / \mathrm{m}^{2} \times 7\right)$ and procarbazine $\left(70 \mathrm{mg} / \mathrm{m}^{2}\right.$ $\times 5)$ by oral administration, every two weeks. Granulocytecolony stimulating factor (G-CSF) was also administered from the third day of each chemotherapeutic course until the next course to support granulocyte recovery. Immediately after four courses of chemotherapy, she suffered a severe herpes zoster infection in her anal, hip and femoral regions with bladder and rectal trouble. With administration of aciclovir $(15 \mathrm{mg} / \mathrm{kg} \bullet$ day $)$ for over three weeks, these symptoms gradually disappeared. She had a complete remission after seven courses of chemotherapy and the $\mathrm{CD} 4+$ lymphocyte count remained decreased during the entire course of treatment (Fig. 2).

\section{Discussion}

ICDL has been defined as a CD $4+T$ cell count of $<300$ cells/ $\mu \mathrm{l}$ or $<20 \%$ of the total $\mathrm{T}$ cells on more than one occasion; negative serological tests for HIV-1 or HIV-2 infection; and no other explanation for the immunodeficiency (7). ICDL is a rare disease with a prevalence of $0.25 \%$ amongst blood donors (8), $1.5 \%$ in HIV-seronegative homosexual men (9) or $0.7 \%$ in patients with abnormally low CD4+ T-lymphocyte counts (10). Previous reports have described cases consistent with ICDL, many being characterized by the existence of one or more risk factors for HIV infection such as homosexuality or intravenous drug use and by concomitant presence of severe opportunistic infection at diagnosis. Many laboratories are now working on identifying the etiologic agents for ICDL. A recent preliminary report described the presence of a retrovirus in an ICDL patient (11), but conclusive evidence of a viral involvement is still unknown.

In the present case, based on her medical history and clinical findings, the diagnosis of ICDL was established, and the patient fulfilled the criteria for longer than nine months. Her CD4+ lymphocytopenia persisted even after complete remission of the malignant lymphoma. Therefore we suggest that the ICDL might be the primary disease and the lymphoma might only be the secondary result or a coincidental disease. Although she had a severe herpes zoster infection during treatment, she denied any risk of HIV infection and she had never suffered from any opportunistic infection despite the fact that her CD4+ cell count was far below 300/ $\mu \mathrm{l}$. Apart from low CD4+ T-lymphocyte counts, the immunologic findings are distinct from the abnormalities found in HIV infection, where CD4+ cell counts exactly reflect the immunological condition and the risk of opportunistic infections is greatly increased when CD4+ cell counts are depressed below 200/ $\mu 1$. However, in patients with ICDL, it is certain that CD4+ cell depletion does not always cause immunodeficiency. We postulate that there might be some other type of ICDL that can result in CD4+ lymphocytopenia without any opportunistic infection or high risk of HIV infection. This form of ICDL is always completely asymptomatic and it is reasonable to conclude that a substantial proportion of cases may not be diagnosed.

The association with malignant lymphoma and immunodeficiency like CD4+ T-lymphocytopenia has raised a great public concern; its etiological and pathological features are investigated precisely in acquired immunodeficiency syndrome (AIDS)-defining illness. Those reports of malignant lymphomas in AIDS patients commonly conclude that the B-cell lymphomas, which usually occur in the extranodal regions, are associated with EB-virus infection (12). The tumorigenic mechanism is considered to be destruction of immunological surveillance and immortalization of B-cells by EB-virus infection leading to B-cell lymphoma development (13). Malignant lymphomas in patients with HIV infection are now thought to be opportunistic with CD4+ T-cell depletion reflecting an insufficiency on the part of the immune response to infection 
CD4+ Lymphocytopenia with Lymphoma

Table 1. Laboratory Data on Admission

\begin{tabular}{|c|c|c|c|}
\hline Peripheral blood exam & & Blood chemical exam & \\
\hline WBC & $6,900 / \mu 1$ & $\mathrm{Na}$ & $139 \mathrm{mEq} / \mathrm{l}$ \\
\hline stab & $28 \%$ & $\mathrm{~K}$ & $4.3 \mathrm{mEq} / \mathrm{l}$ \\
\hline segment & $52 \%$ & $\mathrm{Cl}$ & $104 \mathrm{mEq} / \mathrm{l}$ \\
\hline eosinophil & $1 \%$ & $\mathrm{Ca}$ & $8.5 \mathrm{mg} / \mathrm{dl}$ \\
\hline monocyte & $5 \%$ & BUN & $8 \mathrm{mg} / \mathrm{ml}$ \\
\hline lymphocyte & $14 \%$ & Creatinin & $0.5 \mathrm{mg} / \mathrm{ml}$ \\
\hline $\mathrm{RBC}$ & $4.03 \times 10^{6} / \mu 1$ & Uric acid & $3.6 \mathrm{mg} / \mathrm{ml}$ \\
\hline Hemoglobin & $12.9 \mathrm{~g} / \mathrm{dl}$ & Total protein & $5.40 \mathrm{~g} / \mathrm{dl}$ \\
\hline Hematocrit & $37.5 \%$ & Albumin & $3.5 \mathrm{~g} / \mathrm{dl}$ \\
\hline $\mathrm{MCV}$ & $93.0 \mathrm{fl}$ & ZTT & 6.6 k.u. \\
\hline $\mathrm{MCH}$ & $32.1 \mathrm{pg}$ & TTT & 2.9 k.u. \\
\hline $\mathrm{MCHC}$ & $34.5 \%$ & T-Bilirubin & $0.3 \mathrm{mg} / \mathrm{dl}$ \\
\hline Platelet & $23.6 \times 10^{4} / \mu \mathrm{l}$ & D-Bilirubin & $0.1 \mathrm{mg} / \mathrm{dl}$ \\
\hline Surface Markers & & Alpho & $125 \mathrm{U} / l$ \\
\hline CD3 & $69.8 \% \quad 915 / \mu 1$ & $\gamma$-GTP & $9 \mathrm{U} / l$ \\
\hline CD19 & $26.7 \% \quad 350 / \mu 1$ & LAP & $24 \mathrm{U} / \mathrm{l}$ \\
\hline CD4 & $4.5 \% \quad 43 / \mu l$ & Choline-E & $154 \mathrm{U} / l$ \\
\hline CD8 & $54.5 \% \quad 714 / \mu 1$ & AST & $13 \mathrm{U} / l$ \\
\hline $\mathrm{CD} 4 / 8$ & 0.08 & ALT & $11 \mathrm{U} / l$ \\
\hline CD16 & $11.3 \% \quad 148 / \mu 1$ & $\mathrm{LDH}$ & $132 \mathrm{U} / \mathrm{l}$ \\
\hline CD56 & $16.3 \% \quad 214 / \mu l$ & CPK & $21 \mathrm{U} / l$ \\
\hline \multirow[t]{2}{*}{ Natural killer cell activity } & $19.8 \%$ & Amylase & $38 \mathrm{U} / l$ \\
\hline & & T-cholesterol & $132 \mathrm{mg} / \mathrm{dl}$ \\
\hline Serum exam & & F-cholesterol & $35 \mathrm{mg} / \mathrm{dl}$ \\
\hline CRP & $<0.3 \mathrm{mg} / \mathrm{dl}$ & Glucose & $124 \mathrm{mg} / \mathrm{dl}$ \\
\hline Rheumatoid factor & $<20 \mathrm{IU} / \mathrm{ml}$ & $\mathrm{Fe}$ & $37 \mu \mathrm{g} / \mathrm{dl}$ \\
\hline $\mathrm{IgG}$ & $1,116 \mathrm{mg} / \mathrm{dl}$ & UIBC & $239 \mu \mathrm{g} / \mathrm{dl}$ \\
\hline $\operatorname{IgA}$ & $131 \mathrm{mg} / \mathrm{dl}$ & $\mathrm{Zn}$ & $72 \mathrm{mg} / \mathrm{ml}$ \\
\hline $\operatorname{IgM}$ & $61 \mathrm{mg} / \mathrm{dl}$ & & \\
\hline CEA & $<0.5 \mathrm{ng} / \mathrm{ml}$ & & \\
\hline AFP & $<5 \mathrm{ng} / \mathrm{ml}$ & & \\
\hline CA19-9 & $<10 \mathrm{U} / \mathrm{ml}$ & & \\
\hline RPR & $(-)$ & Bone marrow exam & \\
\hline TPHA & $(-)$ & Cell count & $144 \times 10^{3} / \mu 1$ \\
\hline HBs antigen & $(-)$ & Megakaryocytes & $1 \times 31 / \mu 1$ \\
\hline HBs antibody & $(-)$ & Erythrocytes & $20.4 \%$ \\
\hline HCV antibody & $(-)$ & Granulocytes & $59.4 \%$ \\
\hline HIV-1 antibody & $(-)$ & Monocytes & $3.0 \%$ \\
\hline HIV-2 antibody & $(-)$ & Lymphocytes & $13.4 \%$ \\
\hline
\end{tabular}

MCV: mean corpuscular volume, MCH: mean corpuscular hemoglobin, MCHC: mean corpuscular hemoglobin concentration, CRP: $\mathrm{C}$ reactive protein, CEA: carcinoembryonic antigen, AFP: alpha-fetoprotein, RPR: rapid plasma reagin test, TPHA: treponema pallidum hemagglutination assay, HCV: hepatitis C virus, HIV: human immunodeficiency virus, BUN: blood urea nitrogen, ZTT: zinc sulfate turbidity test, TTT: tymol turbidity test, T-Bilirubin: total bilirubin, D-Bilirubin: direct bilirubin, LAP: leucine aminopeptidase, AST: aspartate aminotransferase, ALT: aranine aminotransferase, LDH: lactate dehydrogenase, CPK: creatine phosphokinase, UIBC: unsaturated iron binding capacity.

contributing to tumorigenesis in association with EB-virus infection. The malignant lymphoma observed in the present case demonstrated the same characteristics as reported for opportunistic lesions, but there have been a few reported cases of ICDL with non-Hodgkin's lymphoma (14). Further immunologic and virologic studies should allow more detailed char- acterization of ICDL and link between underlying immunosuppression and lymphoma development.

Thus this case is instructive in demonstrating the heterogenity of CD4+ T-cell depletion and the association with a malignant lymphoma in an immuno-insufficient state. 


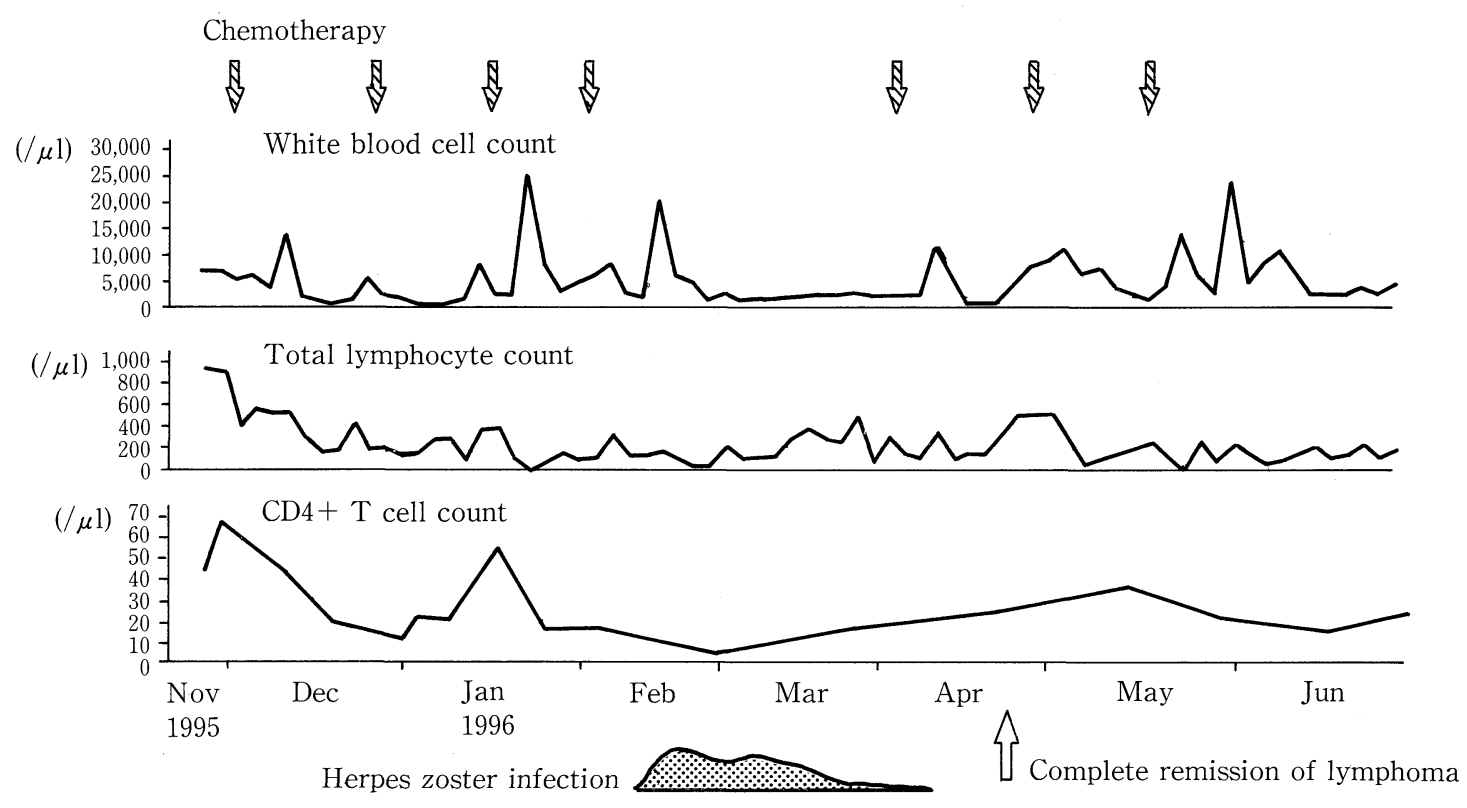

Figure 2. Clinical course of this patient. The CD4+ T-lymphocyte count was strongly depressed before chemotherapy, throughout the chemotherapeutic courses and even after the treatment of malignant lymphoma.

\section{References}

1) Soriano V, Hewlett I, Heredia A, et al. Idiopathic CD4+ T-lymphocytopenia. Lancet 340: 607, 1992 (letter; see comments).

2) Ho DD, Cao Y, Zhu T, et al. Idiopathic CD4+ T-lymphocytopeniaImmunodeficiency without evidence of HIV infection. NEngl J Med 328: 380, 1993 (see comments).

3) Castro A, Pedreira J, Soriano V, et al. Kaposi's sarcoma and disseminated tuberculosis in HIV-negative individual. Lancet 339: 868, 1992 (letter).

4) Jowitt SN, Love EM, Yin JA, Pumphrey RS. CD4 lymphocytopenia without HIV in patient with cryptococcal infection. Lancet 337: 500, 1991 (letter).

5) Pankhurst C, Peakman M. Reduced CD4+ T cells and severe oral candidiasis in absence of HIV infection. Lancet 1989-1: 672, 1989 (letter).

6) Daus H, Schwarze G, Radtke H. Reduced CD4+ count, infections, and immune thrombocytopenia without HIV infection. Lancet 1989-2: 559, 1989 (letter).

7) Spira TJ, Jones BM, Nicholson JK, et al. Idiopathic CD4+ T-lymphocy- topenia - an analysis of five patients with unexplained opportunistic infections. N Engl J Med 328: 386, 1993 (see comments).

8) Busch Mp, Valinsky JE, Paglieroni T, et al. Screening of blood donors for idiopathic CD4+ T-lymphocytopenia. Transfusion 34: 192, 1994.

9) Tindall B, Elford J, Sharkey T, Carr A, Kaldor J, Cooper DA. CD4+ lymphocytopenia in HIV-seronegative homosexual men. AIDS 7: 1272, 1993 (letter).

10) Stasi R, Delpoeta G, Venditti A, Coppetelli U, Masi M, Papa G. Clinical heterogeneity of idiopathic CD4+ T lymphocytopenia. J Intern Med 235: 92, 1994 (letter).

11) Gupta $S$, Ribak CE, Gollapudi $S$, Kim CH, Salahuddin SZ. Detection of a human intracisternal retroviral particle associated with CD4+ T-cell deficiency. Proc Natl Acad Sci USA 89: 7831, 1992.

12) Biemer JJ. Malignant lymphoma associated with immunodeficiency states. Ann Clin Lab Sci 20: 175, 1990.

13) Kersey JH, Shapiro RS, Filipovich AH. Relationship of immunodeficiency to lymphoid malignancy. Pediatr Infect Dis J 7 (suppl 5): 10, 1988.

14) Quiles I, Anaut P, Cibrian F, Gainzarain J, Vega L, Andia A. Idiopathic CD4+ T-lymphocytopenia with opportunistic infection and non-Hodgkin's lymphoma. J Intern Med 238: 183, 1995 (letter). 